\title{
"The overall efficiency of the major banks in the global financial instability"
}

\begin{tabular}{|c|c|c|}
\hline AUTHORS & Igor Yushko & \\
\hline ARTICLE INFO & $\begin{array}{l}\text { Igor Yushko (2016). The overall } \\
\text { financial instability. Banks and } \\
\text { doi:10.21511/bbs.11(4).2016.06 }\end{array}$ & $\begin{array}{l}\text { ajor banks in the global } \\
\text { H), 61-70. }\end{array}$ \\
\hline DOI & http://dx.doi.org/10.21511/bbs.1 & \\
\hline RELEASED ON & Friday, 09 December 2016 & \\
\hline JOURNAL & "Banks and Bank Systems" & \\
\hline FOUNDER & LLC "Consulting Publishing Cor & erspectives" \\
\hline & & $\begin{array}{l}=-0 \\
==\end{array}$ \\
\hline NUMBER OF REFERENCES & NUMBER OF FIGURES & NUMBER OF TABLES \\
\hline 0 & 0 & 0 \\
\hline
\end{tabular}

(C) The author(s) 2023. This publication is an open access article. 
Igor Yushko (Ukraine)

\title{
The overall efficiency of the major banks in the global financial instability
}

\begin{abstract}
The urgency of the issue is due to the change of major banks functioning conditions in accordance with permanent risks, that global financial instability bears, fiscal and monetary regulation enforcement on national financial markets and from the side of supernational institutions of global financial market regulation. The aim of the paper is the research of overall efficiency of the major banks in the global financial instability. The comparative analysis of overall and individual meanings of bank products and services (earnings) sales values, net profit, assets volume, market value of major banks in researched years gave the possibility to find the tendencies of banks development taking into account global financial instability influence and institutional and regulatory foundations of national governments implementation, Financial stability council (created in Ukraine) and Basel Committee on Banking Supervision. The conditions of major global banks functioning are changing under the influence of financial supervision and institutional and regulatory requirements enforcement to banks activity financial parameters. Other factor that provokes global banks towards activity strategy change is the growth of competition both in bank sphere and non-banking institutions in connection to possibilities provided by financial innovations. The directions of further researches lie in global banking effectiveness finding in a whole from the point of view of not separate banks, or group of banks, but global banking system, which, to our mind, has already been formed.
\end{abstract}

Keywords: global financial instability, effectiveness, major banks, global banking, bank efficiency.

JEL Classification: F33, E58, G21.

\section{Introduction}

In relation to global integration of financial markets and transnationalism of financial services providing the conditions of bank institutions functioning are changing. International currency disbalances, permanent crisis of international liquidity, growth of shadow capital use, the pressure on financial markets from the side of high public debt of leading countries, the asymmetry of global capital flow, mobility of trans-border bank capital flows in sum caused global financial instability. Financial instability and permanence of crisis processes in global economic space in its turn lead to unpredictable outcomes in banking sphere. Financial instability promotes the slowdown of world economic progress in a whole, weakening of corporate returns, action change of fundamental force in outer surrounding, moderation of traditional growth factors. The other factor of demand change and demand level to banking services is the implementation of modern information and innovation technologies. The banks face acute competition from non-banking payment systems.

Major banks, on the one hand, are vulnerable to the conditions of global financial instability, and, on the other hand, have great potential to promote the appearance and deepening of financial instability and financial and economic crises. With the aim to neutralize risks, the global financial instability bears, the enforcement of fiscal and monetary regulation

\footnotetext{
${ }^{\odot}$ Igor Yushko, 2016.

Igor Yushko, Chairman of the Board, «SBERBANK» PJSC, Ukraine.
}

on national financial markets takes place, and also supernational regulation institutions of global financial risk are improved, at the same time, on global banking system. Institutional and regulatory events implementation of risks management that appear as a result of financial instability, the growth of outer and inner limits (regulation, capital formation, financing) change the conditions of banks functioning. There appear profitability and productivity fluctuations of banking activity as an adaptation result of global banking system to the financial instability conditions, which is determined by the actuality and importance of research of global banking system overall efficiency.

The paper's aim is the research of overall efficiency of major banks in global financial instability.

\section{Methodology}

The research of overall efficiency of major banks in global financial instability assumes the tackling of issues list: to analyze the concept of global financial instability; to make theoretical analysis of scientific literature on major banks efficiency evaluation, major banks activity interaction and other sectors of economy; to make empirical testing of overall efficiency of major banks in global financial instability on the basis of key parameters analysis, which are general characteristics of major banks' efficiency during financial instability for modern development period.

The comparative analysis of banking activity overall efficiency parameters was held for thirty major world banks. The selected banks are separated as major banks in 2016 Forbes list (for 2015) among 
the largest 2000 public companies and listed in Forbes for the previous researched years, that gives the opportunity to make a comparison between the years. To make empirical researches on the basis of scientific literature analysis (Karcheva, 2015; Kovalenko, Koreneva, 2015; Koziuk, 2009; Kolobov, Pertyk, 2012; Kuznetsova, Kovalenko, 2012; Metodolohiia..., 2005; Remniova, Diadechko, 2011; Slavjuk, Lukjanska, 2015), seven parameters that characterize the overall efficiency of banking activity were outlined (sales value of banking products (earnings), income volume (net profit), assets size, market value (market capitalization), return on sales, return (profitability) on assets, capitalization coefficient). The information according to these parameters is available open accessed (Forbes, 2006, 2008, 2013, 2016).

Calendar year was chosen as a basic time period. The research was held for 2005, 2007, 2012 and 2015, which characterize the global banking system development periods: stable (2005), crisis (2007), post crisis (2013 and 2015 - years connected with Basel III requirements implementation steps).

The findings and conclusions were made on the basis of empirical researches.

\section{Literature review}

Great attention among international experts and scientific world is paid towards the banks' functioning problems under global financial instability. Numerous works of foreign and native scientists are dedicated to the question of comprehensive research of interaction between banking activity and basic types of financial and monetary policies under global financial instability.

Under the auspices of OECD, H.J. Blommestein and $\mathrm{P}$. Turner made a research on interaction between sovereign debt management and monetary policy under fiscal dominance and financial instability and paid attention to the proved fact central banks role enforcement to reach financial stability for the need to reconsider state debt management in this context (Blommestein, Turner, 2012). In the work by V. Mazurenko, the main instruments of state support during financial crisis were outlined: capital infusion, troubled assets purchase, spread of state guaranties on definite types of financial institutions' obligations, providing central bank's liquidity and deposit guaranty schemes spread (Mazurenko, 2013).

I. Azis, V. Bruno, H.S. Shin in the range of works examined efficiency interaction of financial institutions, global banking risks and financial stability appearance. In particular, H.S. Shin suggested the hypothesis and made its empirical research on the existence of cause and effect relation between monetary policy and global banking risks (Azis, Shin, 2015, pp. 4-5). J. Dermine analyzes the Basel committee, OECD and European Union recommendations, for banking corporate government management and, in particular, risk management (Dermine, 2013).

E. Tong researched the causes of global financial instability appearance taking into account US monetary policy and made a conclusion on the need of balancing with warning weakening of tightening monetary policy contributing to the financial system stability. And also concerning the compromise between frequency and width of financial crises. He considers the central banks may effectively provide monetary and macroprudential policies and direct management to improve financial stability (Tong, 2016).

In collective article, V. Bruno and H.S. Shin made an empirical prove of financial instability relation from global liquidity and trans-border capital movement (Bruno, Shin, 2015). Ukrainian authors L. Halperina and L. Lukjanenko determined "on the global market widening under so the called "third platform" of IT development the cost of goods sold and liquidity value is lessened that influences TNC strategies" (Halperina, Lukjanenko, Yatsenko, 2015, p. 92). To our mind, it influences global banking efficiency.

V.V. Koziuk examining monetary framework of global financial stability pays attention to the global banks creditworthiness providing instruments under global financial crisis (Koziuk, 2009).

There is no unified view of scientists according the measure influence on financial stability, thus, Yu.V. Kolobov and O.I. Petryk prove the financial stability providing has to be along with price stability support, the second priority activity function of modern central bank (Kolobov, Petryk, 2012). D.N. Chorafas warns about global banks regulation difficulties and influence of such events on other spheres of economy (Chorafas, 2012). Along with this, some authors consider "getting absolute financial stability should not be the aim and has to be limited by economic efficiency considerations" (Seiranov, Mazylo, 2014). E. Tong stands for the common thesis, who makes conclusions about the compromise between frequency and width of financial crises (Tong, 2016).

N.V. Stukalo, M.V. Lytvyn and G.G. Polishko admit the banking crises are a natural phenomenon in economic system development dynamics in general and are enlarged by currency and debt crises (Stukalo, Lytvyn and Polishko, 2015, p. 57). L.V. Kuznetsova and V.V. Kovalenko found positive and negative influence outcomes of globalization processes on banking system financial stability (Kuznetsova, Kovalenko, 2012, pp. 266-267). Global banking 
activity influence understanding on financial instability has turned the attention of many researchers. V.V. Acharya and $\mathrm{Ph}$. Schnabl provided the proof the geography of 2007-2009 financial crisis was more connected with bank flows, and not with global disbalances. To their mind, the solution of world banking sector predisposition to risks in connection with regulation improvement may lead to the number of cases lessening of global financial crises even in the world where the global disbalances exist (Acharya, Schnabl, 2010).

Ukrainian scientists have made a great scientific contribution into the banking system efficiency research. For example, in the work of V.V. Kovalenko and O.H. Koreneva, the general banking system efficiency statements were made under global competition with empirical research of Ukrainian banking system efficiency (Kovalenko, Koreneva, 2015). L.M. Remniova and L.M. Diadechko examined the general efficiency parameters in the frames of financial stability management of banking entities in modern conditions (Remniova, Diadechko, 2011). Along with this, the issue of general efficiency of global banking system under financial instability was not given enough attention.

Thus, literature review shows the actuality of selected theme and definite scientific uncertainty in the issues of general global banking system efficiency under financial instability.

\section{Modern explanations of global financial in- stability}

For today, there is no generally recognized explanation of "financial instability" and "global financial instability" concepts. Consequently, to search the understanding of global financial instability we will start to study the opposite "financial stability" concept, as well as "global financial stability". The most famous and generally used are the functional features of financial stability proposed by G. Shcinasi in publication arranged under the patronage of IMF, where the author outlines three key functions of financial stability of the system:

- distribution efficiency of economic resources in general and redistribution of resources in time between savings and investment in particular;

- accounting, evaluation and prediction of financial risks;

- merging (absorption) of financial turmoil (shocks) and shocks that come from real economy (Shcinasi, 2007).

As V. Koziuk admits, "global financial stability starts increasingly depend upon:

- firstly, subjective perception of risk that comes from the character of interpretation of the re- sponsibility level between possibilities to support payments deficit and proposition of reliable financial assets;

- secondly, monetary relations between leading countries with opposite payment status, which character may create, and may not create fully the basis for influence interpretation of such relations to the risks content of global financial transactions" (Koziuk, 2009, p. 321).

The objectivity of financialization process is firstly connected with more effective placement of financial resources of global economy on international scale; with transborder movement of financial flows that lead to the appearance of global financial instability. In its turn, numerous researches on the causes of 2007-2009 world financial economic crisis witness about the key role of financial instability state sharp appearance as a result of deregulation, weak debt and monetary policies and ignorance of system risks. The other important finding is the need of financial markets megaregulators enforcement. As the feature of modern global economic system is business transnationalization with the needs in providing high liquidity and transmission from the side of interrelated subjects of global financial market, the national and branch regulation instruments did not correspond with the provided functions for them. The world financial crisis found the drawbacks not only in observation, but also in the falsity of stabilizing events. To avoid the collapse of national financial systems the central banks of the majority of the countries were making the restructure of major banks, and the efficiency of such actions was appeared to be doubtful from the point of getting financial stability on national market. The cause of weak response lies in the transnationalization of banking activity, which is mostly characteristic for major banks.

Native and foreign researchers pay great attention to the procyclicality appearance of global financial stability (Blommestein, Turner, 2012; Dermine, 2013; Obstfeld, 2012; Kuznetsova, Kovalenko, 2012; Seiranov, Mazylo, 2014; Stukalo, Lytvyn and Polishko, 2015). Procyclicality is featured for global financial stability in a whole and banking crises as its performance, in particular, that cannot be but influence the efficiency of major banks functioning. Along with this global financial stability providing provokes currency unions enforcement. Since 2011, the consolidated organs of macro and microprudential observation are acting in the framework of European Union (Seiranov, Mazylo, 2014, p. 38).

$\mathrm{K}$. Velen dedicated scientific research of widespread thought that global financial disbalances are the cause of world financial crisis and arrived to the conclusion it was not the main cause. Lowering of global disbalances must to have secondary meaning. Macroeconomic policy, directed at the 
shortening of global disbalances could be appropriate, but it possibly would not have prevented the crisis. Global political efforts to prevent repeating crisis should be concentrated on the improvement of banking regulation (Smith, Walter, DeLong, 2012). The thought on instability as a source of sustainable dynamic development of global financial market confirms the statement of L.M. Remniovoi and L.M. Diadechko: "Different countries experience learning shows banking crises are the outcome of difficult process of banking systems adaptation towards new macroeconomic conditions" (Remniova, Diadechko, 2011).

Financial stability is a difficult provision process of global financial system essential functions, to which intermediation and risk allocation may be added, financial resources distribution efficiency, payments transmission, price formation on financial instruments.

In conclusion, we admit the functioning of major banks under global financial instability predicts institutional and regulative influence to find and regulate systemic risks, stimulating inner reserves of self regulation at the same time, for effective execution of major banks' functions in global economy providing definite efficiency and trust level from the side of society.

The main causes of global financial instability are high independent risks, international currency disbalances under the unbalanced demand for reserve assets, global liquidity fluctuations, great shadow capital flow, high assets price elasticity, high state debt of leader countries, global capital movement asymmetry, uncertainty on future interest rates.

\section{The role of major banks in global financial instability}

2007-2009 world financial crisis confirmed a system meaning of major banks and their interrelation with other sectors of economy. As empirical researches by V. Bruno and H.S. Shin proved, "all over the world both for developed countries and for countries with merging economy there is a tight connection of global banking system activity and corporate risk" (Bruno, Shin, 2015). The wave of bankruptcies and merging of major banks starting with Lehman Brothers, which later spread to Europe caused the turn of US financial crisis into world financial and economic crisis. Efficiency search caused the bankruptcy and merging of 517 US banks during 2007-2015 (Website Bankratecom).

During 2007-2009, world financial crisis caused insolvency among the biggest banks that executed trans-border banking. For example in Great Britain at the beginning of February 2008 Northern Rock got bankrupt, in the middle of July
Alliance \& Leicester, and in the middle of October - at the same time, Royal Bank of Scotland Group and HBOS (the last one was bought by the government for 22.6 trillion US dollars). In Portugal, insolvent Banco Português de Negócios got 8 trillions of US dollars from government merging. The tenth in size bank of Denmark Roskilde Bank could not find the seller and went under full control of National bank of Denmark. Since 2007 financial troubles befell Swiss global financial company, to which National bank of Switzerland provided capital. In Iceland only in the first half of October 2008 Landsbanki Glitnir, Kaupthing Bank, Lloyds TSB were bought. In December 2008, international Anglo Irish Bank of Ireland announced insolvency, that made the government of Ireland to nationalize it in 2009 , and later on liquidate it in 2011 (according to Website Bankratecom).

G. Dermine proved the finding about the need of accent change in banking system management and stimulating of banks to reject using strategy of short term maximization of income for creating long term value (Dermine, 2013).

After 2007-2008, world financial economic crisis active discussions and considerations were caused by the issue of improvement need of supranational and macroeconomic regulative and institutional framework with the aim to create trust towards policy on financial markets during many years. Along with this, the change of institutional mechanisms for financial instability management may lead to unexpected results and mark the lowering of overall efficiency of such important subjects of global financial market as major banks.

\section{The comparative analysis of the overall effi- ciency of the major banks in the global financial instability}

For the analysis, we chose the banks determined as basic from the list among 2000 largest public companies of the world Forbes Global 2000 (2016), that have the highest parameters of sales volumes in the world, returns, capital and market value, but this list does not fully coincide with the list of systematically important banks that are determined by the Council of financial stability and Basel committee on financial supervision. Among the major banks in 2016 Forbes included 38 banks, but with the aim of comparative analysis of parameters we left 30 establishments from this list, available in the lists of Forbs Global 2006, 2008, 2013 (data for 2005, 2007, 2012). The presence itself of one and the same 30 major banks in the Forbes lists from 2006 witnesses about stability of chosen for research major banks. Table 1 presents 
the rank of major banks in the lists of largest public companies Forbs Global 2000 (according to 2005, 2007, 2012, 2015 companies data). As can be seen from Table 1, during crisis, the parameters of American banks worsened dramatically, which in before crisis period were the leaders of global banking (for example, Wells Fargo and Citigroup). At the same time, the crisis didn't touch JPMorgan Chase, and the rating of Bank of America fell 9 times after the world crisis.

Table 1. The rank of major banks in the lists of largest public companies Forbes Global 2000 $(2005,2007,2012,2015)$

\begin{tabular}{|c|c|c|c|c|c|}
\hline Company name & Country & 2005 & 2007 & 2012 & 2015 \\
\hline ICBC & Hong Kong/China & 1961 & 42 & 1 & 1 \\
\hline JPMorgan Chase & United States & 9 & 4 & 3 & 5 \\
\hline Wells Fargo & United States & 26 & 41 & 12 & 7 \\
\hline Bank of America & United States & 3 & 3 & 28 & 11 \\
\hline Citigroup & United States & 1 & 24 & 19 & 13 \\
\hline HSBC Holdings & United Kingdom & 5 & 1 & 6 & 14 \\
\hline BNP Paribas & France & 17 & 13 & 22 & 24 \\
\hline Banco Santander & Spain & 19 & 21 & 43 & 37 \\
\hline Royal Bank of Canada & Canada & 83 & 55 & 50 & 52 \\
\hline Commonwealth Bank & Australia & 113 & 99 & 40 & 58 \\
\hline Westpac Banking Group & Australia & 161 & 130 & 48 & 72 \\
\hline ANZ & Australia & 146 & 117 & 66 & 84 \\
\hline National Australian Bank & Australia & 86 & 89 & 58 & 88 \\
\hline Bank of Nova Scotia & Canada & 134 & 92 & 84 & 91 \\
\hline US Bancorp & United States & 102 & 118 & 116 & 97 \\
\hline Mizuho Financial & Japan & 44 & 71 & 78 & 106 \\
\hline Société Générale & France & 43 & 102 & 146 & 115 \\
\hline Bank of Montreal & Canada & 169 & 189 & 131 & 143 \\
\hline PNC Financial Services & United States & 291 & 311 & 165 & 153 \\
\hline Bank of New York Mellon & United States & 247 & 183 & 195 & 161 \\
\hline Lloyds Banking Group & United Kingdom & 47 & 54 & 390 & 170 \\
\hline BB\&T & United States & 266 & 315 & 310 & 274 \\
\hline Natixis & France & 384 & 242 & 253 & 305 \\
\hline Barclays & United Kingdom & 20 & 25 & 400 & 420 \\
\hline Royal Bank of Scotland & United Kingdom & 14 & 10 & 420 & 450 \\
\hline FirstRand & South Africa & 361 & 308 & 397 & 502 \\
\hline Standard Chartered & United Kingdom & 232 & 135 & 98 & 516 \\
\hline Regions Financial & United States & 379 & 343 & 568 & 588 \\
\hline KeyCorp & United States & 359 & 538 & 721 & 736 \\
\hline Comerica & United States & 597 & 813 & 987 & 1049 \\
\hline
\end{tabular}

Source: based on Forbes $(2006,2008,2013,2016)$.

Major banks are leaders among the largest companies in the Forbes Global 2000 rank, published in 2016. The first place in the general rank during four years from 2013 till 2016 (2012, 2013, 2014 and 2015 data) takes Industrial and commercial bank of China, abbreviated ICBC (China/Hong Kong). According to the materials of company site, ICBC controls the fifth part of China's banking sector. The bank provides financial services to more than $5.32 \mathrm{mln}$ of corporate and 496 $\mathrm{mln}$ of individual clients. ICBC is one of the global banks having the effective strategies of internationalization and diversification activity. ICBC that covers with its services 42 countries and regions, in 2015 was called "The best bank in emerging markets" from Euromoney (Website ICBC). In 2016, this bank holds primacy in terms of assets volume (3420.3 bln US dollars) among 2000 of the largest world companies, the size of earnings (171.1 bln US dollars), net income
(44.2 bln US dollars) and bank assets - among the biggest banks in the world (Forbes, 2016).

In a whole, 30 major banks chosen for analysis got 1.22 trn US dollars of earnings, 216 bln US dollars of net profit, had 32.3 trn US dollars of assets, and their market value included in a whole 2.3 trn US dollars.

Let's see how the total values of chosen parameters of activity of overall 30 major banks changed in terms of value during researched years (see Tables $2-5)$, that will give the possibility to find the global financial instability influence on them (pre-crisis, crisis and post-crisis periods). The chosen methodology also reflects the influence on financial results of activity of major world banks institutional and regulatory frameworks of national governments, Financial Stability Board, created by G20 countries, and Basel Committee on financial supervision. 
As it is seen from Table 2, the total earnings value was the highest in post-crisis 2012 (1576.6 bln US dollars), accordingly, the average earnings value reached maximum in 2012 (Table 2). Though the standard deviation (mean square) shows how the meanings concerning the average in our sample are distributed. The largest difference in earnings value from the average for thirty major banks is in the meanings of crisis 2007 (44.61 bln US dollars). In other words, at the beginning of crisis the major banks had great differences in banking products sales volumes. Industrial and commercial bank of China (ICBC) in 2005 had the lowest, and from 2012 till 2015 - the highest meaning in other major banks sales volumes, outperforming American global bank Citigroup.

Table 2. The dynamics of earnings volume of thirty world major banks, bln US dollars

$(2005,2007,2012,2015)$

\begin{tabular}{|l|c|c|c|c|}
\hline & 2005 & 2007 & 2012 & 2015 \\
\hline Earnings volume & 954.18 & 1548.94 & 1576.60 & 1215.80 \\
\hline Arithmetic mean & 31.81 & 51.63 & 52.55 & 40.53 \\
\hline Mean square & 29.24 & 44.61 & 40.28 & 36.75 \\
\hline Minimal bank meaning & $\begin{array}{c}4.35 \\
\text { ICBC (China/Hong-Kong) }\end{array}$ & $\begin{array}{c}4.62 \\
\text { Comerica (USA) }\end{array}$ & $\begin{array}{c}2.70 \\
\text { Comerica (USA) }\end{array}$ & $\begin{array}{c}2.80 \\
\text { Comerica (USA) }\end{array}$ \\
\hline Maximum bank meaning & $\begin{array}{c}120.32 \\
\text { Citigroup (USA) }\end{array}$ & $\begin{array}{c}159.23 \text { Citigroup } \\
\text { (USA) }\end{array}$ & $\begin{array}{c}134.80 \text { ICBC } \\
\text { (China/Hong-Kong) }\end{array}$ & $\begin{array}{c}171.10 \text { ICBC } \\
\text { (China/Hong-Kong) }\end{array}$ \\
\hline
\end{tabular}

Source: based on Forbes (2006, 2008, 2013, 2016).

Table 3 demonstrates the growth of profit volume of thirty major world banks from 2005 till 2015. The standard deviation (mean square) also was growing year in, year out. It's interesting, the lowest meanings of minimal profit in reality are bln of losses, English banks Royal Bank of Scotland and Barclays got, which is a financial result of non-crisis, but post-crisis years that in our mind is connected with banking system adaptation towards Basel III implementation. While in 2005, the lowest profit among thirty banks had Industrial and commercial bank of China (ICBC), and, in crisis 2007, American bank Comerica (USA) demonstrated the lowest meaning. The maximum profit got the American Citigroup in 2005 , but, in crisis 2007, when the crisis was raging in the USA, the highest profit got the global financial company HSBC Holdings, with parent body situated in Great Britain. From 2012 till 2015, the leader in volume profit became Industrial and commercial bank of China (ICBC).

Table 3. The dynamics of profit volume of thirty world major banks, bln US dollars $(2005,2007,2012,2015)$

\begin{tabular}{|l|c|c|c|}
\hline & 2005 & 2007 & 2012 \\
\hline Profit volume & 147.36 & 169.91 & 175.00 \\
\hline Arithmetic mean & 4.91 & 5.66 & 5.83 \\
\hline Mean square & 5.22 & 4.88 & 8.28 \\
\hline Minimal bank meaning, name, country & $\begin{array}{c}0.10 \\
\text { ICBC (China/Hong-Kong) }\end{array}$ & $\begin{array}{c}0.69 \text { Comerica } \\
\text { (USA) }\end{array}$ & $\begin{array}{c}-9.40 \text { Royal Bank of Scotland } \\
\text { (Great Britain) }\end{array}$ \\
\hline Maximum bank meaning, name, country & $\begin{array}{c}24.64 \text { Citigroup } \\
\text { (USA) }\end{array}$ & $\begin{array}{c}19.13 \text { HSBC Holdings } \\
\text { (Great Britain) }\end{array}$ & $\begin{array}{c}\text { 37.80 ICBC Barclays } \\
\text { (Great Britain) }\end{array}$ \\
\hline
\end{tabular}

Source: based on Forbes (2006, 2008, 2013, 2016).

The highest assets volume of thirty major banks (35.1 bln US dollars) and average assets of one of the thirty were in 2012 (see Table 4). The highest standard deviation was expected to be in 2007 . Minimal assets in 2005 had Industrial and commer- cial bank of China (ICBC) and it is also a leader from 2012 till 2015. While in pro-crisis and postcrisis period, the maximum assets meanings were among English Barclays and Royal Bank of Scotland accordingly.

Table 4 . The dynamics of assets volume of thirty major world banks, bln US dollars $(2005,2007,2012,2015)$

\begin{tabular}{|c|c|c|c|c|}
\hline Assets & 2005 & 2007 & 2012 & 2015 \\
\hline Total & 16365.08 & 27996.57 & 35089.80 & 32282.40 \\
\hline Arithmetic mean & 545.50 & 933.22 & 1169.66 & 1076.08 \\
\hline Mean square & 512.04 & 927.45 & 881.42 & 845.80 \\
\hline Minimal bank meaning, name, country & $\begin{array}{c}12.78 \\
\text { ICBC (China/Hong-Kong) } \\
\end{array}$ & $\begin{array}{c}62.33 \\
\text { Comerica (USA) }\end{array}$ & $\begin{array}{c}65.40 \text { Comerica } \\
\text { (USA) }\end{array}$ & $\begin{array}{c}69.00 \text { Comerica } \\
\text { (USA) }\end{array}$ \\
\hline Maximum bank meaning, name, country & $\begin{array}{c}1587.06 \\
\text { Barclays (Great Britain) }\end{array}$ & $\begin{array}{l}\text { 3807.51 Royal Bank of Scotland } \\
\text { (Great Britain) }\end{array}$ & $\begin{array}{c}2813.50 \text { ICBC } \\
\text { (China/Hong-Kong) }\end{array}$ & $\begin{array}{c}3420.30 \text { ICBC } \\
\text { (China/Hong-Kong) }\end{array}$ \\
\hline
\end{tabular}

Source: based on Forbes (2006, 2008, 2013, 2016). 
An important parameter is market value of the company. The largest market value of thirty major banks (2.4. bln US dollars) and average assets of one of the thirty banks were in 2012 (see Table 5). Though the standard deviation was the largest in 2015 that was connected with the next stage of Basel III imple- mentation claims. The minimal market value in 2005 was in Industrial and commercial bank of China (ICBC) and it was the leader from 2007 till 2012. In 2016, the first on market value became American global bank Wells Fargo (USA), though its value is lower than the value of ICBC in 2007.

Table 5. The dynamics of market value of thirty major world banks, bln US dollars $(2005,2007,2012,2015)$

\begin{tabular}{|l|c|c|c|c|}
\hline \multicolumn{1}{|c|}{ Market value } & 2005 & 2007 & 2012 & 2015 \\
\hline Total & 1927.98 & 2066.65 & 2365.70 & 2251.70 \\
\hline Arithmetic mean & 64.27 & 68.89 & 78.86 & 75.06 \\
\hline Mean square & 57.29 & 60.88 & 61.53 & 63.48 \\
\hline Minimal bank meaning & $\begin{array}{c}1.44 \text { ICBC } \\
\text { (China/Hong-Kong) }\end{array}$ & 5.45 Comerica (USA) & 6.90 Comerica (USA) & 7.70 Comerica (USA) \\
\hline Maximum bank meaning & 230.93 Citigroup (USA) & $\begin{array}{c}289.57 \text { ICBC } \\
\text { (China/Hong-Kong) }\end{array}$ & $\begin{array}{c}237.30 \text { ICBC } \\
\text { (China/Hong-Kong) }\end{array}$ & $\begin{array}{c}256.00 \text { Wells Fargo } \\
\text { (USA) }\end{array}$ \\
\hline
\end{tabular}

Source: based on Forbes (2006, 2008, 2013, 2016).

Thus, the major banks had the highest total earnings, assets volume, market value parameters in post-crisis 2012, though the highest parameter of total earnings during researched years was in 2015. On the one hand, it shows the adaptation of global banks to the new functioning conditions, and on the other hand about the growth of its overall efficiency.

\section{Profitability of major world banks under global instability}

The research of overall efficiency of banking activity means the analysis of not only absolute meanings, but also the system of interconnected accounting parameters, which give the possibility to prove better the findings on financial bank state. As absolute parameters depend on the size of banking establishment.

Among widely recognized parameters (coefficients) we have chosen the following: sales profitability, assets profitability, overall assets profitability, capital profitability. Sales profitability was calculated as ratio of net profit and sales for the definite year. Overall, assets profitability is calculated as ratio of earnings and assets value for a definite year. Capital profitability - as a ratio of net profit and overall value for a definite year. The calculated coefficients of financial results of major world banks in 2005, 2007, 2012, 2015 are presented in Table 6.

Table 6 . The dynamics of financial results coefficients of thirty major world banks, bln US dollars $(2005,2007,2012,2015)$

\begin{tabular}{|l|c|c|c|c|}
\hline \multicolumn{1}{|c|}{ Coefficient } & 2005 & 2007 & 2012 & 2015 \\
\hline Sales profitability & $15.4 \%$ & $11.0 \%$ & $11.1 \%$ & $17.8 \%$ \\
\hline Assets profitability & $0.9 \%$ & $0.6 \%$ & $0.5 \%$ & $0.7 \%$ \\
\hline Overall assets profitability & $5.8 \%$ & $5.5 \%$ & $4.5 \%$ & $3.8 \%$ \\
\hline Capital profitability & $7.6 \%$ & $8.2 \%$ & $7.4 \%$ & $9.6 \%$ \\
\hline
\end{tabular}

Source: based on Forbes $(2006,2008,2013,2016)$.
Table 6 demonstrates the highest sales profitability and capital profitability parameters in 2015 . Sales profitability means the efficiency use of flows that form it, that is the profitability of every received money unit by bank's earnings. Capital profitability characterizes bank use efficiency of its own capital. Capital profitability coefficient meaning for banks from 5\% and higher witnesses the efficiency. As it can be seen from Table 6, major world banks worked effectively in all researched years, but most effectively in 2015 .

The efficiency of bank management may be evaluated due to assets profitability coefficient use, if this relative index equals $1 \%$ and higher, it means the ability of management to govern bank's assets effectively. Assets profitability was the maximum in pre-crisis 2005 , but lower than $1 \%$ under the crisis and in the first postcrisis years this index was low. We should highlight the positive tendency of this coefficient growth of $0.2 \%$ from 2012 till 2015. As it can be seen from Table 6 , the overall assets profitability is lowering year in, year out from the beginning of researched period. It witnesses about profit level lowering, per unit assets, the bank uses. Assets profitability and overall assets profitability lowering indexes is the reaction of major banks to enforcement of demands towards bank capital and enforcement demands implementation concerning liquidity in Basel III, accepted with the aim of global financial stability strengthening and are being implemented step by step since 2012 .

Along with this, individual meanings of separate major banks witness about their high overall efficiency. For example, sales profitability coefficient of South African FirstRand in 2016 reached 29.3\%, and Industrial and commercial bank of China (ICBC) - 25.8\% (calculated based on data (Forbes, 2016)).

The results of calculations for the first five banks are presented in Table 7 in the Forbes Global 2000 rating announced in 2016. 
Table 7. Financial results coefficients of top 5 major world banks, bln US dollars (2015)

\begin{tabular}{|l|c|c|c|c|}
\hline \multicolumn{1}{|c|}{ Company name } & $\begin{array}{c}\text { Sales } \\
\text { profitability }\end{array}$ & $\begin{array}{c}\text { Overall } \\
\text { assets } \\
\text { profitability }\end{array}$ & $\begin{array}{c}\text { Assets } \\
\text { profitability }\end{array}$ & $\begin{array}{c}\text { Capital } \\
\text { profitability }\end{array}$ \\
\hline ICBC & $25.8 \%$ & $86.4 \%$ & $1.3 \%$ & $22.3 \%$ \\
\hline JPMorgan Chase & $23.5 \%$ & $42.7 \%$ & $1.0 \%$ & $10.0 \%$ \\
\hline Wells Fargo & $22.3 \%$ & $85.3 \%$ & $1.1 \%$ & $19.0 \%$ \\
\hline Bank of America & $24.8 \%$ & $35.7 \%$ & $1.2 \%$ & $8.9 \%$ \\
\hline Citigroup & $17.3 \%$ & $58.7 \%$ & $0.7 \%$ & $10.1 \%$ \\
\hline
\end{tabular}

Source: based on Forbes (2016).

Industrial and commercial bank of China (ICBC) demonstrates the most effective activity among basic competitors on the banking services global market. We should outline high management efficiency of top-5 major banks in the Forbes Global 2000 rank, assets profitability in ICBC, JPMorgan Chase, Wells Fargo, and Bank of America exceeds $1 \%$, and in Citigroup on average level of all investigated banks. All banks demonstrate high meanings of overall assets profitability (ICBC $-86.4 \%$ ). Capital profitability in four of five banks is higher, and in ICBC and Wells Fargo more than twice exceeds average meaning.

Thus, the results of calculations and conducted analysis give the possibility to make a conclusion that banks with the highest absolute indexes also demonstrate the best indexes of overall efficiency.

\section{Findings}

Global financial instability appears as a result of great financial vulnerabilities of world economy from high sovereign risks, international currency disbalances under unbalanced demand for reserve assets, fluctuations of global liquidity, great shadow capital flow, high elasticity of assets prices, high state debt of leader countries, global capital flow asymmetry and uncertainty concerning future interest rates. Major global banks, from one point are vulnerable towards global financial instability conditions, and from the other point have great potential to contribute to appearance and deepening of financial and economic crises.

The comparative analysis of overall and individual meanings of banking products sales value (earnings), profit volume (net profit), assets volume, market value of major banks in investigated years gave the possibility to find the banks development tendencies taking into account global financial instability impact and institution and regulatory frameworks implementation of national governments, financial stability councils and Basel Committee on financial supervision. There is a difference in dynamics of absolute and relative indexes of banking activity. Thus, the highest overall earnings index was in 2012, though sales profitability remained on the level of crisis 2007. The highest index for investigated years of overall earnings was in 2015, this year the major banks demonstrate the highest indexes of sales profitability and capital profitability. This witnesses from one point about new functioning conditions adaptation, and from the other point about the growth of overall efficiency. Low relative indexes of overall major banks management efficiency. Thus, low average indexes of overall assets profitability and assets profitability. The average assets profitability was maximum in pre-crisis 2005, during the crisis and in the first post-crisis years this index was low, but the positive growth tendency was outlined since 2012. The overall assets profitability is lowering year in, year out from 2005 till 2015, which witnesses profit level lowering, per assets unit bank uses. The lowering of assets profitability and overall returns on assets is the reaction of major banks towards the demands enforcement on bank capital and implementation of liquidity enforcement demands in Basel III, that were accepted with the aim to strengthen global financial stability and were implemented step by step since 2012.

Calculations results and conducted analysis give the possibility to make a conclusion the banks with the highest absolute parameters also demonstrate the best indexes of overall efficiency. However, the most part of major banks need flexible strategy on global financial market, efficiency growth and overall efficiency of own activity.

\section{The directions of further researches}

Major global banks functioning conditions are changing under financial supervision enforcement and institutional and regulative demands for the financial parameters of banking activity. An important factor contributing to the activity strategy change of global banks is the competition growth both in banking sphere, and from the side of nonbanking establishments in regards of possibilities, which give financial innovations. That is why the issue of investigation of overall efficiency of global banks under increased competition is important.

Another direction in further investigations is the systematic analysis implementation to the problem of overall efficiency of global banking. As conditions, factors and outcomes of activity of separate elements (separate banks) and components of the system do not provide the image of system functioning as a whole. The directions of further researches mean the global banking efficiency appearance in a whole from the point of view of separate banks, or groups of banks, but global banking system, which, to our mind, has already been formed. 


\section{References}

1. Acharya, V.V., Schnabl, Ph. (2010). Do Global Banks Spread Global Imbalances? Asset-Backed Commercial Paper during the Financial Crisis of 2007-09, IMF Economic Review, August, Volume 58, Issue 1, pp. $37-73$.

2. Azis, I.J. (2015). Managing Elevated Risk Global Liquidity, Capital Flows, and Macroprudential Policy -An Asian Perspective I.J. Azis, H.S. Shin (eBook). Asian Development Bank, Springer Open, p. 129.

3. Blommestein, H.J., Turner, Ph. (2012). Interactions Between Sovereign Debt Management and Monetary Policy Under Fiscal Dominance and Financial Instability, OECD, France, Bank for International Settlements, Switzerland, 20 Feb 2012, No. 3, p. 29.

4. Bruno, V., Shin, H.S. (2014). Globalization of corporate risk taking, Journal of International Business Studies, T. 45, №. 7, pp. 800-820.

5. Bruno, V., Shin, H.S. (2015). Capital flows and the risk-taking channel of monetary policy, Journal of Monetary Economics, Volume 71, April, pp. 119-132.

6. Chorafas, D.N. (2012). Basel III, the Devil and Global Banking. Palgrave Macmillan, p. 285.

7. Claessens, S., Tong, H., Wei, S. (2012). From the financial crisis to the real economy: Using firm-level data to identify transmission channels, Journal of Financial Intermediation, 88, pp. 375-387.

8. Dermine, J. (2013). Bank Corporate Governance, Beyond the Global Banking Crisis, Financial Markets, Institutions \& Instruments, Volume 22, Issue 5, December 2013, pp. 259-281.

9. Forbes. (2006). The World's Biggest Public Companies. Available at: http://www.forbes.com/lists/2006 /18/Banking_Rank_1.html.

10. Forbes. (2008). The World's Biggest Public Companies. The Global 2000. Available at: http://www.forbes.com/ lists/2008/18/biz_2000global08_The-Global-2000_Company.html.

11. Forbes. (2013). 10th Annual Global 2000: The World's Biggest Public Companies. Available at: http://www.forbes.com/sites/forbespr/2013/04/17/forbes-2013-10th-annual-global-2000-the-worlds-biggestpublic-companies/\#10e71e16120e.

12. Forbes. (2016). The World's Biggest Public Companies. Available at: http://www.forbes.com/global2000/list.

13. Magud, N., Reinhart, C., Rogoff, K. (2011). Capital controls: myth and reality - a portfolio balance approach, National Bureau of Economic Research working papers, 16805.

14. Malcolm, Abbott, Wu, Su, Wang, Wei Chun. (2013). The productivity and performance of Australia's major banks since deregulation, Journal of Economics and Finance, January, Volume 37, Issue 1, pp. 122-135.

15. Obstfeld, M. (2012). Financial Flows, Financial Crises, and Global Imbalances, Journal of International Money and Finance, 31, pp. 469-480.

16. Schinasi, G.J. (2007). Understanding Financial Stability [Electronic resource]:Towards a Practical Framework. Available at: http://www.imf.org/external/np/seminars/eng/2006/mfl/gjs.pdf.

17. Smith, R.C., Walter, I., DeLong, G. (2012). Global banking. Oxford University Press, p. 445.

18. Tong, E. (2016). Global financial instability: Why US monetary policy matters, University of Auckland Business Review, Vol. 19, No. 1, pp. 7-15.

19. Whelan, K. (2010). Global imbalances and the financial crisis, University College Dublin. School of Economics, 2010-04. Available at: http://hdl.handle.net/10197/2646.

20. Website Bankratecom. Available at: http: www.bankrate.com/finance.

21. Website ICBC. Available at: http://www.icbc.com.cn/ICBC/About\%20Us/Brief\%20Introduction/ brief $\% 20$ introduction $\% 20$ to $\% 20$ icbc.htm.

22. Halperina, L.P., Lukjanenko, I., Yatsenko, A.Yu. (2015). Finansovi chinnyky stratehii TNK na hlobalnomu ITrynku, Investitsii, praktyka I dosvid, 24, pp. 89-94.

23. Karcheva, H.T. (2015). Systemno-synerhetychnii pidkhid do rozvytku bankivskykh system v emovakh finansovoii nestabilnoati, Problemy ekonomiky, 3, pp. 201-207.

24. Kovalenko, V.V., Koreneva, O.H. (2015). Effektyvnist bankivskoi systemy v umovakh hlobalnoi konkurentsii, pp. 140-144. Available at: http://dspace.oneu.edu.ua.

25. Koziuk, V.V. (2009). Monetarni zasady hlobalnoi finansovoi stabilnosti: monograph, Ternopil: TNEU, Ekonomichna dumka, p. 728.

26. Kolobov, Yu.V., Petryk, O.I. (2012). Osnovni aspekty finansovoi stabilnosti v suchasnykh umovakh Zb. Naukovykh pr. Finansovo-Kredytna dijalnist: problemy teorii ta praktyky. Kharkivskyi instytut bankivskoi spravy Universytetu bankivskoi spravy NBU, 1, pp. 11-17.

27. Kuznetsova, L.V., Kovalenko, V.V. (2012). Vplyv Hlobalizatsiinykh protsesiv na finansovu stiikist bankivskoi systemy, Aktualni problemy ekonomiky, 2 (128), pp. 264-271.

28. Mazurenko, V.P. (2013). Biudgetna polityka v rozvynenykh krainakh v umovakh finansovo-ekonomichnoi kryzy 2008-2009: uroky dlia Ukrainy, Aktualni problemy mizhnarodnykh vidnosyn, 117 (II), pp. 126-136.

29. Metodolohiia reitynhovoi otsinky komertsiinoho banka reitynhovo ahentstva "IBI-Reitynh". Elektronnyi resurs. Available at: http://kbs.org.ua/files/metod_123.pdf.

30. Remniova, L.M., Diadechko, L.M. (2011). Upravlinnia finansovoiu stiikistiu bankivskykh ustanov u suchasnykh umovakh, Naukovyi visnyk Poltavskoho universytetu ekonomiky I torhivli, 6 (51), pp. 249-252. 
31. Seiranov, Yu., Mazylo, T.V. (2014). Konsolidatsiia rehuliuvannia finansovykh rynkiv u Yevropeiskomu Soiuzi v konteksti dosiahnennia finansovoi stabilnosti, Problemu I perspektuvu rozvytku bankivskoi system Ukrainy, Zbirnyk naukovukh prats, 38, pp. 31-41.

32. Slavjuk, R.A., Lukjanska, O.V. (2015). Formuvannia vartosti banku. Tekst: monograph, Lviv: Prostir-M, p. 279.

33. Stukalo, N.V., Lytvyn, M.V., Polishko, H.H. (2015). Teoretyko-metodolohichni osnovy hlobalnoi finansovoi kryzy, Ekonomichnii prostir, 101, pp. 51-61. 